\title{
Klasifikasi Gambar Gigitan Ular Menggunakan Regionprops dan Algoritma Decision Tree
}

\author{
Yoga Widi Pamungkas, Adiwijaya*, Dody Qori Utama \\ Fakultas Informatika, Universitas Telkom, Bandung \\ Email: 1yogawidi1@gmail.com, 2,*adiwijaya@telkomuniversity.ac.id, ${ }^{3}$ dodyqori@telkomuniversity.ac.id \\ *) Email Penulis Korespondensi: adiwijaya@telkomuniversity.ac.id
}

\begin{abstract}
Abstrak-Indonesia memiliki biodiversitas hayati ular yang tinggi. Spesies ular yang ada di seluruh wilayah Indonesia, terdiri dari ular berbisa maupun tidak berbisa. Salah satu bahaya yang dapat ditimbulkan oleh ular adalah gigitan beberapa jenis ular yang mematikan. Kasus gigitan ular yang tercatat di Indonesia cukup tinggi dengan korban meninggal dunia yang tidak sedikit. Sebagian kasus kematian yang disebabkan oleh gigitan ular terjadi karena kesalahan dalam prosedur penanganan pada luka gigitannya. Permasalahan ini bisa diatasi salah satunya apabila mengetahui bagaimana cara untuk mengklasifikasikan luka gigitan ular apakah termasuk berbisa atau tidak berbisa. Pada penelitian ini telah dibangun sistem klasifikasi gambar luka gigitan ular menggunakan ekstraksi ciri Regionprops dan algoritma Decision Tree. Gambar gigitan ular diklasifikasikan termasuk ular berbisa atau tidak berbisa tanpa mengetahui jenis ularnya. Pada Regionprops terdapat beberapa fitur yang digunakan untuk membantu proses ekstraksi ciri, antara lain jumlah centroid, luas area, distance, dan eccentricity. Evaluasi dari model yang telah dibangun didapatkan bahwa parameter jumlah centroid dan jarak antar centroid (distance) memiliki pengaruh paling signifikan dalam membantu klasifikasi gambar luka gigitan ular dengan akurasi 97.14\%, precision $92.85 \%$, recall $91.42 \%$, dan $F 1$ score $92.06 \%$.
\end{abstract}

Kata Kunci: Decision Tree, Regionprops, Gambar Gigitan Ular, Precision, Recall, F1 Score

Abstract-Indonesia has a high biodiversity of snakes. Snake species that exist throughout Indonesia, consisting of venomous and non-venomous snakes. One of the dangers that can be posed by snakes is the bite of several types of deadly snakes. Snake bite cases recorded in Indonesia are quite high with not a few fatalities. Most of the deaths caused by snakebite occur due to errors in the handling procedure for the bite wound. This problem can be overcome one of them if we know how to classify snake bite wounds, whether venomous or non-venomous. In this study, a classification system for snake bite wound image was built using Regionprops feature extraction and Decision Tree algorithm. Snake bite images are classified as either venomous or non-venomous without knowing the kind of the snake. In Regionprops several features are used to help the process of feature extraction, including the number of centroids, area, distance, and eccentricity. Evaluation of the model that was built was found that the parameters of the number of centroids and the distance between centroids had the most significant influence in helping the classification of images of snakebite wounds with an accuracy of $97.14 \%$, precision $92.85 \%$, recall $91.42 \%$, and F1 score $92.06 \%$.

Keywords: Decision Tree, Regionprops, Snake Bites, Precision, Recall, F1 Score

\section{PENDAhuluan}

Indonesia merupakan negara tropis dengan keanekaramagaan hayati yang tinggi. Biodiversitas flora yang ada di Indonesia mencapai 20.000 spesies, dengan $40 \%$ merupakan tumbuhan endemik Indonesia [1]. Spesies fauna seperti mamalia, burung, reptil, dan ikan mencapai 8.157 jenis [2]. Sekitar $16 \%$ spesies amfibi dan reptil yang ada di dunia hidup di Indonesia, dengan jumlah lebih dari 1.100 spesies [3]. Dari sekian banyak spesies reptil di Indonesia, ular adalah salah satu reptil yang dibagi menjadi dua jenis, yaitu berbisa dan tidak berbisa. Spesies ular yang ada di Indonesia sekitar 450 jenis, dengan persebarannya dibagi menjadi dua kelompok berdasarkan asal geografis [4]. Kelompok yang pertama terdiri dari spesies ular yang memiliki kesamaan dengan ular asal Asia yang berada di sebelah barat garis Wallace (Sumatra, Jawa, Kalimantan, dan Bali). Kelompok kedua memiliki kesamaan dengan wilayah Australia-Papua. Wilayah ini berada di sebelah timur garis Wallace (Papua Barat dan Maluku) [5].

Banyaknya jenis ular yang ada di Indonesia berbanding lurus dengan tingkat kasus gigitan ular yang terjadi. Gigitan ular adalah salah satu permasalahan yang menimbulkan korban jiwa. Perkiraan data kasus gigitan ular yang tercatat di Indonesia sebanyak 113.811 kasus, dengan korban jiwa diperkirakan berjumlah 5.800 [6], [7]. Perkiraan ini berdasarkan laporan penelitian dan mungkin terdapat perbedaan dengan kasus yang sebenarnya. Ada banyak faktor yang mempengaruhi perbedaan ini, seperti kasus gigitan ular yang terjadi di daerah pedesaan, sehingga tidak sampai ke rumah sakit dan tidak ada laporan [8]. Sehingga jumlah kasus gigitan ular mungkin lebih besar dari yang diperkirakan.

Kasus gigitan ular banyak terjadi di kalangan penduduk pedesaan yang miskin, pekerja pertanian, penggembala, nelayan, pemburu, anak-anak yang bekerja (usia 10-14 tahun), penduduk yang memiliki edukasi yang terbatas, dan jauh dari pusat perawatan medis [9]. Dari berbagai kalangan tersebut, sangat minim pengetahuan dalam menangani kasus gigitan ular. Sebagian kasus kematian yang disebabkan oleh gigitan ular terjadi karena kesalahan dalam prosedur penanganan luka pada gigitannya [8]. Penanganan yang dilakukan untuk saat ini masih dilakukan secara tradisional dan manual. Hal ini disebabkan oleh kurangnya teknologi yang dapat digunakan untuk mempermudah klasifikasi gigitan ular. Permasalahan ini bisa diatasi salah satunya dengan mengetahui bagaimana cara untuk mengklasifikasi jenis ular berdasarkan luka gigitan ular. 
Penelitian ini bertujuan untuk mengklasifikasikan gambar luka gigitan ular menggunakan Regionprops sebagai ekstraksi ciri dan Decision Tree sebagai model klasifikasinya. Serta mengetahui parameter mana yang berpengaruh dalam membantu klasifikasi. Sebagai data masukan dari sistem ini adalah gambar bagian tubuh yang hanya terdapat bekas gigitan ular. Decision Tree merupakan salah satu metode dalam Machine Learning yang mampu divisualisasikan dan mudah untuk dimengerti serta diimplementasikan. Decision Tree cocok digunakan pada penelitian ini karena mendukung biner classification serta dapat memperoleh hasil yang maksimal walaupun dengan data latih yang tidak terlalu banyak [10]. Sedangkan regionprops adalah salah satu ekstraksi fitur dari image processing yang dapat mengambil fitur-fitur dari suatu gambar.

Sistem yang dibangun hanya dapat mengklasifikasikan gambar sebagai gigitan ular berbisa atau tidak berbisa tanpa mengetahui jenis dari ular tersebut. Serta dapat mengetahui parameter apa yang paling optimal dari fitur ekstraksi ciri Regionprops dalam membantu klasifikasi gambar gigitan ular.

Beberapa penelitian telah dilakukan untuk mengklasifikasikan jenis ular, baik berdasarkan gambar gigitannya maupun gambar dari ular secara langsung. Seperti penelitian oleh Alex J. pada tahun 2017 [11] yang mengklasifikasikan berbagai jenis ular berdasarkan gambar. Metode yang digunakan yaitu klasifikasi k-Nearest Neighbor (kNN) dengan bantuan ekstraksi fitur Scale-Invariant Feature Transform SIFT. Hasil dari penelitian tersebut diketahui bahwa apabila digunakan rasio 0.9 akan memperoleh 634 fitur yang cocok, dengan akurasi yang didapatkan 95,9\%. Penelitian lain untuk klasifikasi jenis ular dilakukan oleh Kalana [12]. Penelitian tersebut menguji darah korban apakah terdapat enzim Phospholispase A2 di dalam darah atau tidak. Pada umumnya enzim tersebut terdapat pada ular berbisa.

Penelitian yang dilakukan oleh Rayiemas pada tahun 2018 [13] untuk mengklasifikasikan ular berbisa atau tidak menggunakan ekstraksi fitur chain code dan juga kNN. Nilai akurasi yang didapatkan pada penelitian tersebut sebesar $76.92 \%$ dengan nilai K adalah 13. Saran yang diberikan pada penelitian tersebut yaitu mengganti metode klasifikasi dan juga menfokuskan pada tahap preprocessing.

Pada tahun 2019, Hermawati juga membangun sistem yang bisa mengidentifikasi ular berdasarkan gigitannya bmenggunakan Local Binary Patern (LBP) dan juga Support Vector Machine (SVM) [14]. LBP digunakan sebagai fitur ekstraksi yang dapat menghasilkan karakteristik dari gambar input dalam bentuk histogram, sedangkan SVM untuk klasifikasinya. Pada penelitian ini dilakukan dua skenario. Skenario yang pertama dengan mengubah parameter point $(\mathrm{P})$ dan radius (r) pada LBP. Sedangkan yang kedua pada parameter $\mathrm{C}$ dan sigma pada SVM. Hasil yang didapatkan dengan parameter $\mathrm{P}=8, \mathrm{r}=1, \mathrm{C}=1$ dan sigma $=0,15$ menghasilkan akurasi sebesar $89 \%$.

Aydadenta pada 2018 [15] melakukan klasifikasi menggunakan random forest yang dikombinasikan dengan seleksi fitur berbasis clustering. Akurasi yang diperoleh adalah $98.9 \%$ untuk kanker paru, $89 \%$ untuk kanker prostat, dan $85.87 \%$ untuk kanker usus besar. Amalya melakukan penelitian pada tahun 2018 [16] untuk mendeteksi kanker menggunakan Algoritma Binary Particle Swarm Optimization (BPSO) dan C4.5 Decision Tree. Dari penelitian yang dilakukan, performansi dari sistem yang dibangun untuk lima data yang digunakan mendapatkan rata-rata akurasi 54\% untuk skema klasifikasi dengan Information Gain sebagai seleksi fitur dan rata-rata akurasi $99 \%$ untuk skema klasifikasi dengan BPSO sebagai seleksi fitur. Pemilihan nilai $\mathrm{k}$ pada diskritisasi didapatkan hasil yang terbaik adalah nilai $\mathrm{k}=5$.

Shoumy pada tahun 2016 [17] melakukan penelitian tentang fitur ekstraksi untuk mengenali pola pada darah menggunakan Neural Network. Regionprops adalah fitur yang digunakan untuk mengenali pola objek dengan cara mengekstraksi karakteristik dasar dari noda darah. Di dalam fitur ini terdapat beberapa fitur lagi, diantaranya 'Area', 'Centroid', 'MajorAxisLength', 'MinorAxisLength', dan lainnya. Hasil dari Regionprops ini yang akan diolah menggunakan 2 tipe dari Neural Network, yaitu cascade forward neural network (CFNN) and function fitting neural network (FFNN). Hasil yang diperoleh bahwa FFNN lebih baik daripada CFNN dengan hasil $91.1 \%$ dan $86.6 \%$.

\section{METODE PENELITIAN}

Sistem pada penelitian ini dibagi menjadi beberapa tahap yaitu, tahap preprocessing, tahap ekstraksi ciri, dan tahap pengujian model klasifikasi. Gambar 1 menunjukkan flowchart dari sistem. 


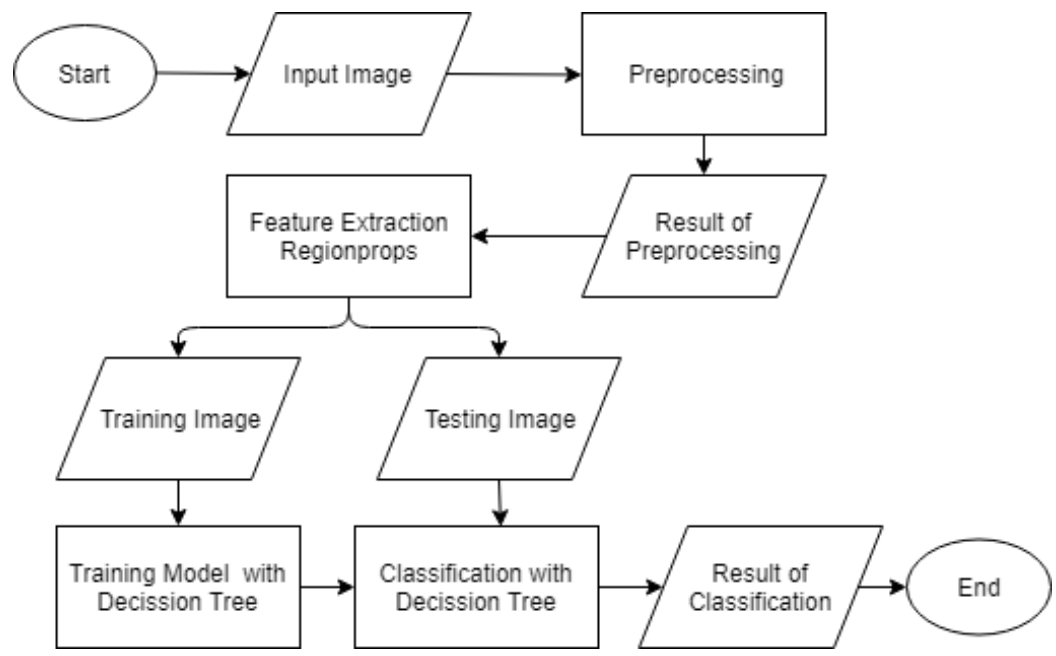

Gambar 1. Flowchart dari sistem

\subsection{Dataset}

Data yang digunakan dalam penelitian ini adalah dataset gambar luka gigitan ular yang terdiri dari 34 gambar gigitan ular dengan 16 gambar ular berbisa dan 18 tidak berbisa. Gambar 2 adalah contoh dari gambar gigitan ular berbisa dan tidak berbisa yang digunakan sebagai input pada penelitian ini.

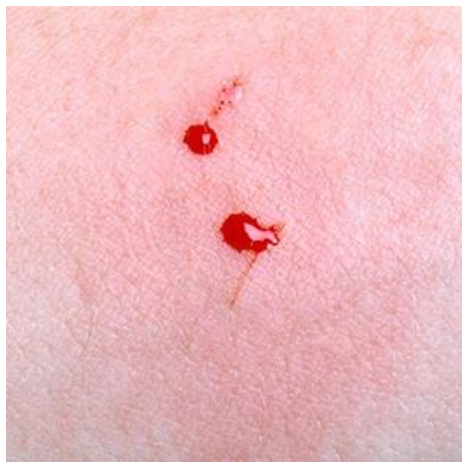

(a)

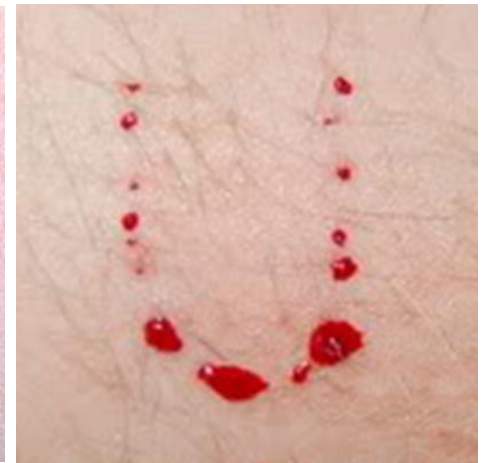

(b)

Gambar 2. Gambar gigitan ular berbisa (a) dan gambar gigitan ular tidak berbisa (b)

\subsection{Preprocessing}

Tahap pertama yaitu preprocessing. Beberapa diantara gambar input masih memiliki noise yang akan mengganggu dalam proses klasifikasi. Noise yang dimaksud berupa citra gigitan ular yang tidak jelas, blur pada saat pengambilan gambar, dan terdapat objek yang lain di sekitar luka gigitan. Maka dari itu perlu dilakukan preprocessing untuk menangani data tersebut. Pada awalnya gambar diedit terlebih dahulu menggunakan aplikasi pengolah gambar Photoshop untuk menghilangkan noise yang tidak bisa dihilangkan oleh sistem. Gambar yang digunakan sebagai data memiliki format RGB, yang terdiri dari 3 warna : merah (red), hijau (green), dan biru (blue). Pada proses preprocessing dilakukan thresholding untuk masing-masing warna dan kemudian digabungkan. Hasil dari thresholding ini dalam bentuk blackwhite (bw). Karena masih ada bagian-bagian yang belum terisi sempurna pada gambar dilakukan fill holes menggunakan fitur imfill. Langkah terakhir dari preprocessing yaitu menggunakan fitur strel ('disk', 25) untuk menghilangkan noise yang masih tersisa.

\subsection{Ekstraksi Ciri Regionprops}

Hasil dari preprocessing selanjutnya masuk ke tahap ekstraksi. Penelitian ini menggunakan Regionprops sebagai fitur ekstraksi. Hasil dari ekstraksi ini berupa ciri khusus yang merepresentasikan gambar input. Ada beberapa fitur yang dapat dipakai di dalam Regionprops. Fitur yang dipakai pada penelitian ini antara lain, centroid, crea, dan eccentricity. Centroid merepresentasikan titik bekas luka gigitan luar. Area merepresentasikan luas masingmasing centroid.

Fitur Centroid akan menghasilkan koordinat dari masing-masing objek yang ada pada suatu gambar. Dengan fitur ini dapat mengetahui dua macam parameter, yaitu jumlah objek pada suatu gambar yang merupakan jumlah luka gigitan dari ular dan juga jarak rata-rata antar objek. Berdasarkan pengamatan, jumlah luka gigitan pada ular berbisa berkisar antara 1 sampai 4 luka, sedangkan untuk ular tidak berbisa meninggalkan bekas luka lebih dari 4. Jarak rata-rata antar objek dihitung menggunakan metrik pengukuran Euclidean Distance. 


$$
\begin{gathered}
d=\sum_{i=i}^{k-1} \sum_{j=1+k}^{k} \sqrt{\left(x_{i}-x_{j}\right)^{2}+\left(y_{i}-y_{j}\right)^{2}} \\
\bar{d}=\frac{d}{k}
\end{gathered}
$$

Pada persamaan (1) digunakan untuk menghitung jarak rata-rata (distance) antar setiap objek. Variabel $d$ merupakan jarak antara dua buah objek. Variabel $x$ dan $y$ adalah koordinat suatu objek yang didapatkan dari fitur centroid. Variabel $k$ adalah jumlah dari centroid yang ada pada gambar. Sedangkan variabel $\bar{d}$ merupakan jarak rata-rata antara semua objek yang ada.

$$
A=\sum_{i=1}^{k} a_{i}
$$

Fitur area menghasilkan nilai luas dari masing-masing objek pada gambar. Persamaan (3) untuk menghitung nilai luas total dari semua objek yang ada. Variabel A merepresentasikan luas total dari semua objek. Variabel $k$ adalah jumlah dari objek yang ditemukan pada gambar, $a_{i}$ merepresentasikan luas objek ke $i$.

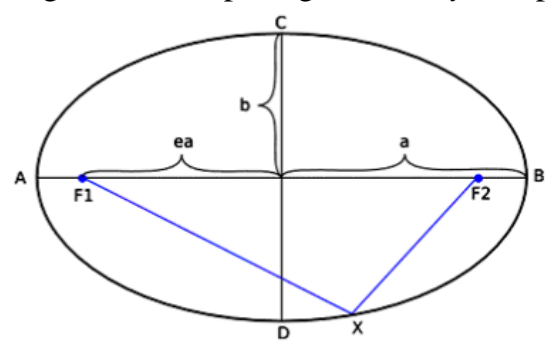

Gambar 3. Ilustrasi eccentricity

$$
e=\sqrt{1-\frac{b^{2}}{a^{2}}}
$$

Fitur eccentricity digunakan untuk membedakan bentuk suatu objek dengan lainnya. Nilai perbandingan antara jarak foci ellips minor dengan foci ellips mayor suatu objek. Eccentricity memiliki rentang nilai antara 0 hingga 1. Objek yang berbentuk memanjang/mendekati bentuk garis lurus, nilai eccentricity-nya mendekati angka 1 , sedangkan objek yang berbentuk bulat/lingkaran, nilai eccentricity-nya mendekati angka 0 . Variabel $e$ merepresentasikan eccentricity, variabel a sebagai mayor axis, sedangkan b sebagai minor axis.

\subsection{Klasifikasi Menggunakan Algoritma Decision Tree}

Setelah melewati tahap ekstraksi ciri, data yang ada kemudian dipisah menjadi data latih dan data uji. Data latih selanjutnya akan masuk ke dalam tahap klasifikasi menggunakan Decision Tree. Decision Tree adalah salah satu jenis klasifikasi yang merepresentasikan bentuk dari struktur pohon. Dimana setiap node merepresentasikan atribut, cabang merepresentasikan nilai dari atribut, dan dau merepresentasikan kelas. Pada penelitian ini kedalaman tree maksimal yang digunakan adalah empat.

Pada penelitian ini menggunakan algoritma C4.5. Algoritma C4.5 merupakan pengembangan dari algoritma ID3. Secara umum, algoritma C4.5 untuk membangun pohon keputusan adalah sebagai berikut: (i) Pilih atribut sebagai root, (ii) Buat cabang untuk masing-masing nilai, (iii) Bagi kasus dalam cabang, dan (iv) Ulangi prosesuntuk masing-masing cabang sampai semua kasus pada cabang memiliki kelas yang sama.Pemilihan atribut sebagai root didasarkan pada nilai gain tertinggi dari atribut-atribut yang ada. Untuk menghitung gain digunakan Persamaan (1) [18].

$$
\operatorname{Gain}(S, A)=\operatorname{Entropy}(S)-\sum_{i=1}^{n} \frac{\left|S_{i}\right|}{S} * \operatorname{Entropy}\left(S_{i}\right)
$$

Dimana $S$ adalah notasi himpunan kasus dan A untuk notasi atribut. Variabel $n$ menyatakan jumlah partisi atribut A dan partisi ke $i$ dinotasikan dengan $\left|S_{i}\right|$. Untuk perhitungan entropi dapat dilihat pada persamaan berikut. 


$$
\operatorname{Entropy}(S)=\sum_{i=1}^{n}-p i * \log _{2} p i
$$

Pada persamaan di atas variabel $\mathrm{n}$ mewakili jumlah partisi atribut $\mathrm{S}$. Kemudian $p i$ menyimpan nilai proporsi dari $S_{i}$ terhadap $S$.

Parameter yang digunakan untuk proses pengujian sistem antara lain: jumlah centroid, luas area, jarak ratarata antar objek (distance), dan eccentricity. Pada tahap pengujian juga digunakan $K$-fold validation. Dimana data akan dibagi menjadi $K$ bagian. Setiap bagiannya akan bergantian berperan sebagai data uji.

\subsection{Confusion Matrix}

Evaluasi dari kualitas model data diukur dengan membangun confusion matrix. Dari confusion matrix akan didapatkan nilai akurasi, precision, recall, dan F1 score. Akurasi adalah perbandingan antara kelas prediksi yang sebenarnya dengan kelas prediksi. Precision adalah rasio prediksi positif yang dilakukan dengan benar terhadap total prediksi positif. Recall menunjukkan rasio prediksi positif yang dilakukan dengan benar terhadap seluruh kelas yang ada. Sedangkan F1 score adalah rata-rata dari nilai precision dan recall.

$$
\begin{gathered}
\text { Accuracy }=\frac{T P+T N}{T P+F P+F N+T N} \\
\text { Precision }=\frac{T P}{T P+F P} \\
\text { Recall }=\frac{T P}{T P+F N} \\
F 1 \text { score }=2 \frac{\text { Recall } x \text { Precision }}{R+P}
\end{gathered}
$$

Dimana TP (True Positive) adalah jumlah semua diprediksi positif dan benar positif. TN (True Negatif) merupakan jumlah yang diprediksi salah. FP (False Positive) merupakan kelas yang seharusnya diklasifikasikan positif namun diprediksi negatif. FN (False Negative) ketika diprediksi negatif ternyata bernilai positif.

Ada beberapa rumus untuk menghitung akurasi, precision, recall, dan F1 score. Beberapa diantaranya dengan cara micro-averaging, macro-averaging, dan weighted averaging. Karena pada penelitian ini hanya membedakan dua kelas, yaitu ular berbisa dan tidak berbisa, maka menggunakan macro-averaging. Perhitungan macro dilakukan berdasarkan kelas masing-masing. Berikut adalah rumus untuk menghitung dengan cara macroaveraging.

$$
\begin{gathered}
\text { Macro }- \text { Precision }=\frac{\text { Precision } 1+\text { Precision } 2}{2} \\
\text { Macro }- \text { Recall }=\frac{\text { Recall } 1+\text { Recall } 2}{2} \\
\text { Macro }-F 1 \text { score }=2 \frac{(\text { Macro }- \text { Precision }) \cdot(\text { Macro }- \text { Recall })}{(\text { Macro }- \text { Precision })+(\text { Macro }- \text { Recall })}
\end{gathered}
$$

\section{HASIL DAN PEMBAHASAN}

\subsection{Hasil Pengujian}

Pengujian sistem dilakukan untuk menemukan parameter yang paling optimal dan akurat dalam membantu klasifikasi gambar gigitan ular. Jumlah K yang dipakai pada penelitian ditentukan dengan mencari kombinasi nilai yang paling optimal dari hasil akurasi, precision, recall, dan F1 score. Pada penentuan jumlah $\mathrm{K}$ yang akan digunakan, parameter yang dipakai antara lain: jumlah centroid, luas area, distance, dan eccentricity. Tabel 1 menunjukkan hasil penentuan $k$-fold.

Tabel 1. Hasil pengujian k-fold

\begin{tabular}{lllll}
\hline K-fold & Akurasi & Precision & Recall & F1 Score \\
\hline
\end{tabular}




\begin{tabular}{ccccc}
\hline 3 & 94.19 & 66.66 & 63.73 & 65.14 \\
4 & 91.31 & 62.55 & 58.12 & 60.19 \\
5 & 93.80 & 80.0 & 76.98 & 78.32 \\
6 & 91.11 & 75.0 & 70.55 & 72.55 \\
7 & 94.28 & 85.71 & 82.85 & 84.12 \\
8 & 91.25 & 81.25 & 76.87 & 78.76 \\
\hline
\end{tabular}

Berdasarkan Tabel 1 diketahui bahwa $k$-fold yang paling optimal adalah 5 dan 7 . Pada penelitian kali ini dilakukan dua skenario untuk menentukan parameter yang paling berpengaruh dalam mengklasifikasikan gambar gigitan ular. Skenario pertama menggunakan 5-fold validation, yang berarti perbandingan proporsi data latih dan data uji adalah 80:20. Skenario kedua menggunakan 7-fold validation, dengan perbandingan data latih dan data uji 85:15. Tabel 2 dan 3 menunjukkan skenario pengujian yang dilakukan.

Tabel 2. Hasil pengujian pada skenario pertama dengan 5-fold validation

\begin{tabular}{|c|c|c|c|c|c|c|c|}
\hline \multirow[b]{2}{*}{$\begin{array}{l}\text { Jumlah } \\
\text { Centroid }\end{array}$} & \multicolumn{3}{|c|}{ Parameter yang digunakan } & \multirow[b]{2}{*}{ Akurasi } & \multirow[b]{2}{*}{ Precision } & \multirow[b]{2}{*}{ Recall } & \multirow[b]{2}{*}{ F1 Score } \\
\hline & Luas Area & Distance & Eccentricity & & & & \\
\hline Ya & - & - & - & 93.80 & 87.55 & 85.83 & 86.23 \\
\hline- & Ya & - & - & 58.09 & 51.66 & 35.00 & 40.36 \\
\hline- & - & Ya & - & 97.14 & 90.00 & 88.57 & 89.23 \\
\hline- & - & - & $\mathrm{Ya}$ & 90.95 & 77.55 & 74.40 & 75.46 \\
\hline Ya & Ya & - & - & 93.80 & 87.50 & 85.83 & 86.23 \\
\hline Ya & - & Ya & - & 93.80 & 80.00 & 76.90 & 78.32 \\
\hline Ya & - & - & $\mathrm{Ya}$ & 93.80 & 87.50 & 85.83 & 86.23 \\
\hline- & Ya & Ya & - & 97.14 & 90.00 & 88.57 & 89.23 \\
\hline- & Ya & - & $\mathrm{Ya}$ & 90.95 & 77.50 & 74.40 & 75.46 \\
\hline- & - & $\mathrm{Ya}$ & $\mathrm{Ya}$ & 97.14 & 90.00 & 88.57 & 89.23 \\
\hline Ya & Ya & $\mathrm{Ya}$ & $\mathrm{Ya}$ & 93.80 & 80.00 & 76.90 & 78.32 \\
\hline
\end{tabular}

Tabel 3. Hasil pengujian pada skenario kedua dengan 7-fold validation

\begin{tabular}{cccccccc}
\hline $\begin{array}{c}\text { Jumlah } \\
\text { Centroid }\end{array}$ & Parameter yang digunakan & & & & & \\
\hline Ya Area & Distance & Eccentricity & Akurasi & Precision & Recall & F1 Score \\
- & - & - & - & 94.28 & 90.44 & 89.04 & 89.20 \\
- & Ya & - & - & 55.00 & 55.95 & 37.73 & 43.01 \\
- & - & Ya & - & 97.14 & 92.85 & 91.42 & 92.06 \\
Ya & - & - & Ya & 91.42 & 83.33 & 80.47 & 81.26 \\
Ya & Ya & - & - & 94.28 & 90.47 & 89.04 & 89.20 \\
Ya & - & Ya & - & 94.28 & 85.71 & 82.85 & 84.12 \\
- & - & - & Ya & 94.28 & 90.47 & 89.04 & 89.20 \\
- & Ya & Ya & - & 97.14 & 92.85 & 91.42 & 92.06 \\
- & - & Ya & Ya & 91.42 & 83.33 & 80.47 & 81.26 \\
Ya & Ya & Ya & Ya & 97.14 & 92.85 & 91.42 & 92.06 \\
& & & & 94.28 & 85.71 & 82.85 & 84.12 \\
\hline
\end{tabular}


Pada grafik di bawah ini adalah hasil tree yang didapatkan ketika hanya menggunakan parameter distance.

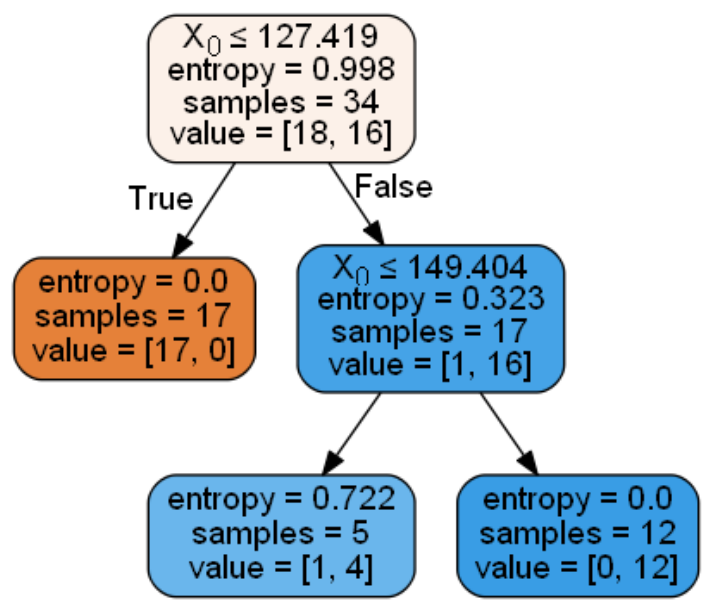

Gambar 4. Model Decision Tree ketika menggunakan parameter distance

\subsection{Analisis Hasil Pengujian}

Pada pengujian sistem skenario pertama dengan 5-fold falidation didapatkan hasil bahwa parameter distance apabila digunakan sendiri mendapatkan akurasi, precision, recall, dan F1 score yang paling tinggi yaitu masingmasing $97.14 \%, 90.00 \%, 88.57 \%$, dan $89.23 \%$. Sedangkan yang paling rendah adalah parameter luas area dengan akurasi $58.09 \%$, precision $51.66 \%$, recall $35.00 \%$, dan $F 1$ score $40.36 \%$. Ketika dua parameter digunakan secara bersamaan terbukti bahwa parameter distance dapat tetap memperoleh hasil pengujian yang tinggi. Parameter jumlah centroid mendapatkan hasil dibawah parameter distance, dengan akurasi $93.80 \%$, precision $87.55 \%$, recall 85.83\%, dan F1 score 86.23\%. Pada Gambar 4 menunjukkan contoh model tree yang dihasilkan ketika menggunakan parameter distance. Didapatkan hasil bahwa pada root, entropi yang didapatkan 0.99. Ketika parameter distance dan jumlah centroid digunakan secara bersamaan justru menghasilkan nilai yang lebih rendah dibandingkan jika digunakan bersama parameter eccentricity dan luas area. Terdapat perbedaan disaat dalam memprediksi suatu gambar yang sama ketika parameter jumlah centroid dan distance digunakan secara bersamaan.

Skenario kedua menggunakan 7-fold falidation yang secara umum menghasilkan nilai yang agak berbeda dengan skenario pertama. Parameter jumlah centroid mengalami peningkatan hasil dengan akurasi $94.28 \%$, precision $90.44 \%$, recall $89.04 \%$, dan F1 score $89.20 \%$. Peningkatan yang lain juga dialami oleh parameter eccentricity, sedangkan parameter luas area mengalami penurunan akurasi menjadi $55.00 \%$.

Pada kedua skenario parameter luas area menjadi parameter yang paling tidak optimal. Hal ini terjadi karena parameter luas area sangat bergantung pada saat pengambilan gambar yang digunakan untuk data latih. Semakin dekat jarak pengambilan gambar, semakin besar pula luas area yang dihasilkan. Sehingga parameter luas area kurang optimal sebagai parameter dalam mengklasifikasikan gambar gigitan ular.

\section{KESIMPULAN}

Pada penelitian ini telah dilakukan serangkaian penelitian untuk menemukan nilai terbaik dalam klasifikasi gambar gigitan ular menggunakan ekstraksi ciri regionprops dan Decision Tree sebagai algiritma clasifier. Kombinasi dari beberapa parameter dari regionprops telah diterapkan untuk mencari tahu parameter yang paling berpengaruh dalam klasifikasi. Hasil dari penelitian ini diketahui bahwa kombinasi parameter distance dengan luas area atau dengan eccentricity ketika menggunakan 7-fold validation menghasilkan nilai yang paling tinggi dengan akurasi $97.14 \%$, precision $92.85 \%$, recall $91.42 \%$, dan $F 1$ score $92.06 \%$.

Parameter jumlah centroid dan distance sama-mana berbengaruh besar dalam penelitian ini. Apabila digunakan secara terpisah, kedua parameter ini menghasilkan nilai yang tinggi. Namun apabila digunakan secara bersamaan nilai yang dihasilkan menurun dikarenakan terdapat suatu gambar input yang memiliki kualitas kurang bagus, sehingga terdapat perbedaan antara value gambar yang asli dengan yang sudah diproses. Kemudian parameter luas area tidak terlalu berpengaruh pada penelitian ini, sehingga apabila digunakan secara bersamaan dengan parameter lain, nilai yang dihasilkan akan mengikuti parameter lain tersebut. Hal ini terjadi karena parameter luas area sangat bergantung pada saat pengambilan gambar yang digunakan untuk data latih. Semakin dekat jarak pengambilan gambar, semakin besar pula luas area yang dihasilkan. Sehingga parameter luas area kurang optimal sebagai parameter dalam mengklasifikasikan gambar gigitan ular.

Beberapa data pada penelitian yang kualitasnya kurang bagus menyebabkan hasil pada tahap preprocessing kurang optimal. Pada penelitian mendatang diharapkan menggunakan data yang lebih baik dan juga dilakukan penambahan data. Apabila pada penelitain mendatang dilakukan penambahan data, maka dapat menggunakan model yang lain sebagai klasifikasinya. Kemudian tidak hanya mengklasifikasikan antara ular berbisa dan tidak 
berbisa, namun dapat ditambahkan klasifikasi pada jenis-jenis bisa ular, seperti neurotoksin, hemotoksin, dan lainnya.

\section{REFERENCES}

[1] Kusmana, C. (2015). The Biodiversity of Flora in Indonesia. Bogor Agricultural University.

[2] Yuwono, A. (2014). The Fifth National Report Of Indonesia To The Convention On Biological Diversity. Ministry Of Environment And Forestry Of Indonesia.

[3] BAPPENAS (1993). Biodiversity Action Plan for Indonesia. Ministry of National Development Planning/National Development Planning Agency, Jakarta, Indonesia. 141 p.

[4] Latus, P., Panaro, F. (2018). Venomous Snakes - Snakebites. Introducing Indonesia, 5th edition, AWA. Available at : https://www.expat.or.id/medical/venomoussnakes.html

[5] Auerbach PS, Norris RL. (2015). Disorders caused by venomous snakebites and marine animal exposures. In: Harrison's principles of internal medicine. 18th ed. Vol. 2. New York: McGraw-Hill Professional. p. 3566-76

[6] Gutiérrez JM, Warrell DA, Williams DJ, et al. (2013). The need for full integration of snakebite envenoming within a global strategy to combat the neglected tropical diseases: the way forward. PLoS Negl Trop Dis 7(6):e2162

[7] International Society on Toxinology. (2014). http://knoema.com/ueecokg/global-snakebite-statistics-may-2014

[8] Kasturiratne A, Wickremasinghe AR, de Silva N, et al. (2008). The global burden of snakebite: a literature analysis and modelling based on regional estimates of envenoming and deaths. PLoS Med. 5(11):e218.

[9] World Health Organization (2016). https://www.who.int/snakebites/epidemiology/en/

[10] Gupta, B., Rawat, A., Jain, A., et al. (2017). Analysis of Various Decision Tree Algorithms for Classification in Data Mining. International Journal of Computer Applications (0975 - 8887)

[11] James, A. (2017). Snake classication from images. PeerJ Preprints 5.

[12] Maduwage, K., O'leary, M.A., \& Isbister, K.G. (2014) Diagnosis of snake envenomation using a simple phospholipase A2 assay. Scientific reports 4 .

[13] Putra, R. M., Adiwijaya \& Utama, D.Q. (2018). Snake Bite Classification Using Chain Code and K Nearest Neighbour. Journal of Physics: Conference Series.

[14] Hernawati, N.P.A.U.D, Adiwijaya, \& Utama, D. Q. (2018). Image processing for snake indentification based on bite using Local Binary Pattern and Support Vector Machine method. Journal of Physics: Conference Series, 1192:012007

[15] Husna Aydadenta, Adiwijaya, (2018), A Clustering Approach for Feature Selection in Microarray Data Classification using Random Forest, Journal of Information Processing System 14(5)

[16] Amalya Citra Pradana1, Adiwijaya2, Annisa Aditsania3. (2018). Implementing binary particle swarm optimization and C4.5 decision tree for cancer detection based on microarray data classification. Journal of Physics Conference Series 1192:012014

[17] Shoumy, N. J., Yaakop, S.N., Ehkan, P., Ali, M. S., \& Khatun, S. (2016). Feature extraction for neural network pattern recognition for bloodstain image analysis. International Journal of Applied Engineering Research, 11(15):8583-8589.

[18] Craw, S. (2005). Case Based Reasoning. Lecture 3 : CBR Case-Base Indexing. Available at : www.comp.rgu.ac.uk/staff/ smc/teaching/cm3016/Lecture-3-cbr-indexing.ppt 